\title{
Editorial
}

\section{Profiles in Family Nursing Leadership: Honoring the Authors of Family Nursing Textbooks}

On June 2, 2005, a special honoring ceremony, sponsored by the Journal of Family Nursing, was held at the 7th International Family Nursing Conference in Victoria, British Columbia, Canada. The Distinguished Contribution to Family Nursing Award was created to recognize outstanding contribution to family nursing through cumulative career achievement or a single contribution that has played a seminal role in the field. At this conference, the award focused on substantive publication in family nursing and acknowledged the sustained efforts of authors and editors of family nursing textbooks that have been published in more than a second edition. Numerous textbooks and monographs about the nursing of families have been published during the past 25 years (see the appendix) - a tribute to the growth of empirical knowledge and clinical scholarship within the field. However, there are a small handful of authors whose diligent efforts have had a significant influence on shaping family nursing theory and practice through their writing and revising of family nursing textbooks throughout many years. These distinguished authors are listed in order of the publication date of their first edition:

Dr. Marilyn M. Friedman, Family Nursing: Research, Theory, and Practice (5th ed., 1981, 1986, 1992, 1998, 2003)

Dr. Lorraine M. Wright and Dr. Maureen Leahey, Nurses and Families: A Guide to Family Assessment and Intervention (4th ed., 1984, 1994, 2000, 2005)

Dr. Perri J. Bomar, Promoting Health in Families: Applying Family Research and Theory to Nursing Practice (3rd ed., 1989, 1996, 2004)

Dr. Shirley M. H. Hanson, Family Health Care Nursing: Theory, Practice, and Research (3rd ed., 1996, 2001, 2005)

We salute all of the authors of family nursing textbooks, and we honor particularly the five who recently received the Distinguished Contribution to Family Nursing Award for their leadership and dedication to family nursing.

Janice M. Bell, R.N., Ph.D. Editor 


\section{APPENDIX \\ Family Nursing Textbooks and Monographs (1980 to 2005)}

The following are listed by publication date from earliest to most recent:

Miller, J. R., \& Janosik, E. H. (1980). Family-focused care. New York: McGraw Hill.

Friedman, M. M. (1981). Family nursing: Theory and assessment. New York: Appleton-Century-Crofts.

Wright, L. M., \& Leahey, M. (1984). Nurses and families: A guide to family assessment and intervention. Philadelphia: F. A. Davis.

McFarlane, J. M. (1986). The clinical handbook of family nursing. New York: John Wiley.

Friedman, M. M. (1986). Family nursing: Theory and assessment (2nd ed.). Norwalk, CN: Appleton-Century-Crofts.

Leahey, M., \& Wright, L. M. (Eds.). (1987). Families \& life-threatening illness. Philadelphia: Springhouse.

Leahey, M., \& Wright, L. M. (Eds.). (1987). Families \& psychosocial problems. Philadelphia: Springhouse.

Wright, L. M., \& Leahey, M. (Eds.). (1987). Families \& chronic illness.

Philadelphia: Springhouse.

Gilliss, C. L., Highley, B. L., Roberts, B. M., \& Martinson, I. M. (1989). Toward a science of family nursing. Menlo Park, CA: Addison-Wesley.

Bomar, P.J. (1989). Nurses and family health promotion: Concepts, assessment and interventions. Philadelphia: Saunders.

Bell, J. M., Watson, W. L., \& Wright, L. M. (Eds.). (1990). The cutting edge of family nursing. Calgary, Alberta, Canada: Family Nursing Unit Publications. (Selected papers from the First International Family Nursing Conference).

Ross, B., \& Cobb, K. L. (1990). Family nursing: A nursing process approach. Redwood City, CA: Addison-Wesley Nursing.

Whall, A. L., \& Fawcett, J. (Eds.). (1991). Family theory development in nursing: State of the science and art. Philadelphia: P. A. Davis. 
Berkey, K. M, \& Hanson, S. M. H. (1991). Pocket guide to family assessment and intervention. St. Louis, MO: Mosby.

Friedman, M. M. (1992). Family nursing: Theory and assessment (3rd ed.). Norwalk, CN: Appleton \& Lange.

Wegner, G. D. \& Alexander, R. J. (Eds.). (1993). Readings in family nursing. Philadelphia: J. B. Lippincott.

Feetham, S. L., Meister, S. B., Bell, J. M., \& Gilliss, C. L. (Eds.). (1993). The nursing of families: Theory/research/education/practice. Newbury Park, CA: Sage. (Selected papers from the 2nd International Family Nursing Conference).

Danielson, C. B., Hamel-Bissell, B., \& Winstead-Fry, P. (1993). Families, health, and illness: Perspectives on coping and intervention. St. Louis, MO: Mosby.

Wright, L. M., \& Leahey, M. (1994). Nurses and families: A guide to family assessment and intervention (2nd ed.). Philadelphia: F. A. Davis.

Duhamel, F. (Ed.). (1995). La santé et la famille: Une approche systémique en soins infirmiers [Health and the family: A systemic approach for nursing care]. Montreal, Quebec, Canada: Gaétan Morin.

Friedemann, M. L. (1995). The framework of systemic organization: A conceptual approach to families and nursing. Thousand Oaks, CA: Sage.

Bomar, P. J. (1996). Promoting health in families: Applying family research and theory to nursing practice (2nd ed.). Philadelphia: Saunders.

Wright, L. M., Watson, W. L., \& Bell, J. M. (1996). Beliefs: The heart of healing in families and illness. New York: Basic Books.

Hanson, S. M. H., \& Boyd, S. T. (1996). Family health care nursing: Theory, research and practice. Philadelphia: F. A. Davis.

Whyte, D. A. (Ed.). (1997). Explorations in family nursing. London: Routledge.

Vaughan-Cole, B., Johnson, M. A., Malone, J. A., \& Walker, B. L. (1998). Family nursing practice. Philadelphia: Saunders.

Friedman, M. M. (1998). Family nursing: Research, theory and practice (4th ed.). Stamford, CN: Appleton \& Lange.

Broome, M., Knafl, K., Feetham, S., \& Pridham, K. (1998). Children and families in health and illness. Thousand Oaks, CA: Sage. 
Wegner, G. D., \& Alexander, R. J. (Eds.). (1999). Readings in family nursing (2nd ed.). Philadelphia: J. B. Lippincott.

Wright, L. M., \& Leahey, M. (2000). Nurses and families: A guide to family assessment and intervention (3rd ed.). Philadelphia: F. A. Davis.

Schober, M., \& Affara, F. A. (2001). The family nurse: Frameworks for practice. Geneva, Switzerland: International Council of Nurses.

Hanson, S. M. H. (2001). Family health care nursing: Theory, research and practice. Philadelphia: F. A. Davis.

International Council of Nurses. (2002). Nurses always there for you: Caring for families (Information and action tool kit). Geneva, Switzerland: Author.

Denham, S. A. (2003). Family health: A framework for nursing. Philadelphia: F A. Davis.

Friedman, M. M., Bowden, V. R., \& Jones, E. G. (2003). Family nursing: Research, theory and practice (5th ed.). Upper Saddle Ridge, NJ: Prentice Hall.

Bomar, P.J. (2004). Promoting health in families: Applying family research and theory to nursing practice (3rd ed.). Philadelphia: Saunders.

Wright, L. M., \& Leahey, M. (2005). Nurses and families: A guide to family assessment and intervention (4th ed.). Philadelphia: F. A. Davis.

Hartrick Doane, G., \& Varcoe, C. (2005). Family nursing as relational inquiry: Developing health-promoting practice. Philadelphia: Lippincott Williams \& Wilkins.

Hanson, S. M. H., Kaakinen,J., \& Gedaly-Duff, V. (2005). Family health care nursing: Theory, practice, and research (3rd ed.). Philadelphia: F.A. Davis. 